\title{
ОСОБЛИВОСТІ ЕМПАТІЇ НА РІЗНИХ ЕТАПАХ ПРОФЕСІЙНОГО СТАНОВЛЕННЯ ПРАКТИЧНИХ ПСИХОЛОГІВ СИСТЕМИ ОСВІТИ
}

\author{
Ганна Пирог \\ кандидат філософських наук, доцент, \\ доцент кафедри психології розвитку та консультування \\ Житомирський державний університет імені Івана Франка \\ 10008, Україна, м. Житомир, вул. Велика Бердичівська, 40 \\ sevtur73@gmail.com, https://orcid.org/0000-0002-5139-0286
}

\author{
Наталія Шикирава \\ методист з психологічної служби науково-методичного центру \\ Департамент освіти Житомирської міської ради \\ 10014, Україна, м. Житомир, вул. Велика Бердичівська, 7 \\ shukurava1976@ukr.net,https://orcid.org/0000-0002-8903-1027
}

\begin{abstract}
Анотація
Дослідження емпатії практичних психологів та іï трансформацій на різних стадіях професійного становлення є важливим для попередження емоційного вигорання фахівців, збереження їхнього психологічного здоров'я. Метою статті стало вивчення особливостей емпатії у практичних психологів системи освіти на різних етапах професіогенезу. Для емпіричного вивчення показників емпатії було використано «Тест на визначення емпатії» Л. Журавльової, для з'ясування особливостей суб'єктивного переживання різних етапів професійного розвитку досліджуваних - методику «Професійний шлях» Г. Пирог.

Результати дослідження засвідчили, що для практичних психологів системи освіти найбільш характерними $є$ середній і високий рівні емпатійності. Серед форм емпатії домінують активні емпатійні ставлення, пов'язані 3 емоційною і дієвою підтримкою людини. Прояви емпатії пов'язані з віком - чим старшим є психолог, тим вища його загальна емпатійність, хоча при цьому він менше переживає 3 приводу почуттів іншого. Зв'язок емпатії зі стажем виявлено лише в групі «молодих фахівців»: на початку професійної діяльності відбуваються досить інтенсивні зміни в проявах емпатії у напрямку зменшення iї загального прояву і збільшення антиемпатії. Це пояснюється особливостями професійного становлення, а саме: змінами в емоційних оцінках професійно значущих подій, їх підсумках, характері труднощів, що призводить до усвідомлення власних проблем і зниження емпатійності. Після періоду професійної адаптації ставлення психологів системи освіти до власної професії починає мати менш емоційний і більш «інструментальний» характер. Вищий рівень емпатійності виявляється у тих досвідчених психологів, які в професійній діяльності орієнтуються на інших людей і мають високу емоційність. Подальші дослідження плануються у напрямі вивчення зв'язку емпатії практичних психологів з локусом контролю, а також розробці програми розвитку оптимальних емпатійних ставлень для попередження емоційного вигорання.
\end{abstract}


Ключові слова: емпатія, емпатійне ставлення, професійне становлення, практичні психологи, система освіти, професійний шлях.

\section{Вступ}

Трансформації сучасного суспільства актуалізують проблеми постійного розвитку та самовизначення особистості у професійній сфері. Для професій 3 деонтологічним статусом, до яких належать і психологи, основним інструментом професійної реалізації $є$ особистісні якості. Однією з основних характеристик ефективного психолога є емпатія складне психологічне утворення, що одночасно належить до особистісної та професійної сфери практичного психолога. Дослідження емпатії практичних психологів системи освіти, особливостей їх змін на різних стадіях професійного розвитку є необхідним для визначення стратегій супроводу фахівців у процесі їх професійного становлення, для підвищення якості праці, попередження емоційного вигорання, збереження психологічного здоров'я.

Емпатія розглядається у різних наукових галузях, які вивчають проблеми взаємодії між людьми. В психологічних дослідженнях переважають два підходи до розуміння емпатії (Журавльова, 2007): у першому емпатія трактується як процес або стан, наприклад, у роботах G. Barrett-Lennard (Barrett-Lennard, 1981), В. Бойка (Бойко, 2004) та ін.; у другому - як здатність чи стійка властивість особистості, наприклад, у роботах Т. Гаврилової (Гаврилова, 1974) та ін. Науковці трактують емпатію, переважно, у трьох основних напрямах: як когнітивний феномен, тобто інтелектуальний процес пізнання іншої людини, наприклад, J. Hakansson (Hakansson, 2003), О. Бодальов (Бодалев, 1996); як афективний, тобто емоційний стан здатності співпереживання іншій особі, наприклад, A. Goldstein, G. Michaels (Goldstein \& Michaels, 1985), В. Бойко (Бойко, 2004); як поведінковий, тобто активну взаємодію та сприяння іншим особам, наприклад, Ю. Гіппенрейтер, Т. Карягина, О. Козлова (Гіппенрейтер \& etc., 1993). Л. Журавльова (Журавльова, 2007) виокремила п’ять основних тенденцій у розумінні феноменології емпатії та визначила емпатію, як складний афективно-когнітивний процес; взаємодію емоційних, когнітивних i конативних компонентів; цілісне утворення когнітивних, емоційних і моторних компонентів (синергетичний рівень розвитку емпатії). В сучасній науці переважає думка, що емпатія - це складний і багатовимірний феномен, який потребує міждисциплінарного підходу з використанням психологічних, соціологічних, освітніх, нейрологічних моделей і розробки надійних методів дослідження (Neumann \& etc., 2009).

У сучасних дослідженнях часто вивчається вплив емпатії на якість допомоги фахівців у сферах психології, психотерапії, медицини, соціальної роботи. Результати досліджень доводять, що емпатія досить сильно впливає на результати терапії (Elliott \& etc., 2011), вона має глибокий терапевтичний потенціал у стосунках із пацієнтом (клієнтом) i визначає високу якість допомоги (Neumann \& etc., 2009), знижує занепокоєність і стрес у пацієнтів, тим самим забезпечує підвищення їхніх ресурсів і рівня задоволеності (Derksen \& etc., 2013).

Розвинену емпатію вважають одним із визначальних чинників успішної професійної діяльності практичних психологів (Василюк, 2007; Роджерс, 1995). Вміння проникати та приймати світ іншої людини, приєднатися до клієнта, подивитися на 
проблему і ситуацію, наче зсередини, є необхідною професійною якістю психотерапевта, психолога-консультанта (Горностай, 2018).

В дослідженнях, що присвячені проблемам професіогенезу психологів, науковці звертають увагу на важливість емпатії під час підготовки до професії (Бражникова, 2012; Дерев'янко, 2015; Чаплак, 2018). Основою для формування професійної емпатії $є$ особистий досвід психологів, який усвідомлюється та «оформлюється» під час навчання (Карягина, 2010). Для розвитку емпатії дуже важливим $є$ забезпечення фахівців відповідними вміннями допомоги (Hong \& Han, 2020), зокрема навчання певним навичкам розуміння і співчуття до людей, що відрізняються за своїми характеристиками (Lu \& etc., 2020).

В процесі професійної діяльності в емпатії практичних психологів та інших фахівців, які працюють 3 людьми, відбуваються зміни. Тривала робота 3 травмованими клієнтами може привести психологів і соціальних працівників до виснаження, втоми або «задоволення від співчуття» (Craig \& Sprang, 2009). Дослідження свідчать, що емпатія найменшою мірою виявляється у молодих лікарів 3 малим стажем роботи й у лікарів 3 великим професійним досвідом (Мітіна, 2017); у молодих психологів і соціальних працівників більш високий рівень вигорання, а у досвідчених - більш високий рівень задоволеності співчуттям (Craig \& Sprang, 2009), водночас у менш досвідчених фахівців емпатія сильніше впливає на результати терапії, ніж у більш досвідчених (Elliott \& etc., 2011). Зі зростанням професійного стажу цінність емпатії для професійної діяльності психологів збільшується, при цьому фахівці починають оцінювати себе, як більш емпатійних (Немолот \& Зубова, 2013).

Загалом дослідники вважають, що для емпатійних проявів провідними факторами $\epsilon$ багаторічний досвід і вік (Craig \& Sprang, 2009), інтеграція біографічного досвіду фахівця і ситуаційних факторів (Neumann \& etc., 2009). Проте, в окремих дослідженнях відзначено, що рівні прояву емпатії у психологів-консультантів, які лише починають працювати за фахом, і в досвідчених фахівців практично не відрізняються (Goussakovski \& Sizikova, 2017).

Отже, огляд досліджень емпатії підтверджує іiі важливість для професійної діяльності практичних психологів, для надання ними якісної психологічної допомоги. Ключовими факторами для розвитку емпатії є досвід (професійний та особистий) і вік фахівця, однак дані про зіставлення емпатії й досвіду в професійній діяльності мають протиріччя. Тому питання змін, які відбуваються в емпатії практичних психологів на різних етапах професійного становлення, залишається дискусійним і потребує додаткових досліджень.

Метою дослідження $є$ визначення особливостей емпатії практичних психологів системи освіти на різних етапах їхнього професійного становлення. Для досягнення мети дослідження визначено такі завдання: 1) з'ясувати рівень емпатійності в психологів закладів освіти; 2) провести порівняльний аналіз показників емпатії в групах психологів із різним стажем практичної діяльності; 3) визначити наявність зв'язку проявів емпатії 3 віком і стажем практичних психологів; 4) з'ясувати особливості розвитку емпатійності в контексті суб'єктивного переживання професійного становлення досліджуваних. 


\section{Методи дослідження}

Дослідження проводилося з урахуванням вікових особливостей і стажу роботи (досвідченості) психологів закладів освіти. У дослідженні взяли участь 56 психологів закладів дошкільної та загальної середньої освіти Житомира (Україна) з різним стажем практичної діяльності - від 0,5 до 26 років. Всі досліджувані - жінки.

Для вирішення завдань дослідження вибірка була поділена на три групи за критерієм тривалості професійної діяльності. Розуміючи, що формування професіоналізму та майстерності відбувається з різною швидкістю і за індивідуальними траєкторіями, все ж групам було надано умовні назви, що відповідають етапам професійного розвитку та самовизначення: «молоді фахівці», «професіонали» і «майстри». В першу групу респондентів («молодих фахівців») увійшло 13 психологів (23\% від всієї вибірки) 3 професійним стажем від 0,5 до 3 років, у віці від 24 до 45 років. До другої групи респондентів («професіоналів») увійшло 22 психологи (39\% вибірки) з професійним стажем від 4 до 14 років, у віці від 30 до 49 років. До третьої групи респондентів («майстрів») увійшов 21 психолог (38\% вибірки) з професійним стажем від 15 до 26 років, у віці від 34 до 66 років.

Для емпіричного дослідження показників емпатії використовувався «Тест на визначення емпатії» Л. Журавльової, який дозволяє виявити загальний показник емпатійності, її окремі форми та рівні розвитку (Журавльова, 2011). А саме такі форми: антиемпатію, індиферентність (пасивне споглядання ситуації), співпереживання (егоцентричне емпатійне ставлення), співчуття (суб'єктноцентричне емпатійне ставлення), внутрішне сприяння (пасивне емпатійне ставлення), реальне сприяння не на шкоду собі (активне емпатійне ставлення), реальне сприяння на шкоду собі (дієве трансцендентне емпатійне ставлення). За сумою показників всіх форм емпатії визначається інтегральна емпатія і рівень ії розвитку: дуже низький, низький, середній, високий, дуже високий.

Для з'ясування особливостей суб'єктивного переживання професійного становлення досліджуваних було використано методику «Професійний шлях» (Пирог, 2020), яка дозволяє визначити етапи професійного розвитку, професійні події та кризи, емоційні переживання, професійні труднощі та способи їх подолання.

Обробка, аналіз та узагальнення результатів емпіричного дослідження проводилися 3 використанням методів математичної статистики. Для з'ясування загального рівня емпатії психологів, форм емпатії та їхнього зіставлення було застосовано дескриптивну статистику - обчислення середнього арифметичного i середнього квадратичного відхилення. Для порівняльного аналізу показників емпатії у групах із різним стажем практичної діяльності використовувалося обчислення статистично значущих відмінностей за допомогою непараметричного критерію Манна-Уїтні. Психологічні особливості розвитку емпатії на різних етапах професіоналізації визначались за допомогою виявлення та інтерпретації кореляційних зв'язків показників емпатії з віком і стажем (коефіцієнт рангової кореляції Спірмена).

\section{Результати та дискусії}

Аналіз дескриптивної статистики вибірки психологів закладів освіти за віком і стажем (табл. 1) засвідчив, що середній вік всіх учасників дослідження - 37,87 років при середньому стажі роботи психологом 10,66 років, у групі «молодих фахівців»- 31 рік при 
середньому стажі роботи 1,55 років, у групі «професіоналів»-37,05 років при середньому стажі роботи 9,44 років, у групі «майстрів» - 43,53 роки при середньому стажі роботи 17,59 років.

Таблиияя 1

Характеристики вибірки психологів освітніх закладів

\begin{tabular}{|c|c|c|c|c|}
\hline \multirow{2}{*}{ Вибірка } & \multicolumn{2}{|c|}{ Вік } & \multicolumn{2}{c|}{ Стаж } \\
\cline { 2 - 5 } (за стажем) & $\mathrm{M}$ & $\sigma$ & $\mathrm{M}$ & $\sigma$ \\
\hline $0,5-3$ років & 31 & 6,73 & 1,55 & 1,05 \\
\hline $4-14$ років & 37,05 & 5,72 & 9,44 & 2,51 \\
\hline 15-26 років & 43,53 & 9,1 & 17,59 & 3,21 \\
\hline $0,5-26$ років (вся вибірка) & 37,87 & 8,64 & 10,66 & 6,7 \\
\hline
\end{tabular}

Примітка: $M$ - середнє значення, $\sigma$-середнє квадратичне відхилення

Визначення рівня інтегральної емпатії у вибірці засвідчило, що для психологів закладів освіти найбільш характерним є середній $(71,4 \%)$ і високий $(23,2 \%)$ рівні емпатії. Низький рівень мають 5,4\% досліджуваних. Аналіз емпатії за іiі формами показав, що найчастіше досліджувані демонструють «реальне сприяння не на шкоду собі» (79\%). Для частини психологів характерні змішані варіанти емпатійного ставлення: «реальне сприяння не на шкоду собі» в поєднанні з «реальним сприянням на шкоду собі» $(5,5 \%)$, зі «співчуттям» (2\%), «антиемпатією» (2\%). У 5,5\% досліджуваних переважає «реальне сприяння на шкоду собі», ще у $2 \%$ ця форма поєднується з «індиферентністю». По $2 \%$ психологів у ситуаціях взаємодії виявляють «індиферентність» і «співчуття».

Для з'ясування особливостей прояву i загального рівня різних форм емпатії («антиемпатія», «індиферентність», «співпереживання», «співчуття», «внутрішнє сприяння», «реальне сприяння не на шкоду собі», «реальне сприяння на шкоду собі», «інтегральна емпатія») у психологів із різним професійним стажем був проведений порівняльний аналіз їхніх статистичних показників (див. табл. 2).

Таблиия 2

Показники форм емпатії психологів закладів освіти з різним професійним стажем

\begin{tabular}{|c|c|c|c|c|c|c|c|c|}
\hline \multirow[t]{3}{*}{ Форми емпатії } & \multirow{2}{*}{\multicolumn{2}{|c|}{$\begin{array}{c}\text { Вся } \\
\text { вибірка }\end{array}$}} & \multicolumn{6}{|c|}{ Групи психологів (за стажем) } \\
\hline & & & \multicolumn{2}{|c|}{ 0,5-3 років } & \multicolumn{2}{|c|}{ 4-14 років } & \multicolumn{2}{|c|}{ 15-26 років } \\
\hline & $\mathrm{M}$ & $\sigma$ & $\mathrm{M}$ & $\sigma$ & $\mathrm{M}$ & $\sigma$ & $\mathrm{M}$ & $\sigma$ \\
\hline Антиемпатія & 0,71 & 0,69 & 0,62 & 0,82 & 0,64 & 0,47 & 0,86 & 0,77 \\
\hline Індиферентність & 0,73 & 0,74 & 0,85 & 1,33 & 0,68 & 0,5 & 0,71 & 0,5 \\
\hline Співпереживання & 0,79 & 1,24 & 0,69 & 0,5 & 0,82 & 0,47 & 0,81 & 2,03 \\
\hline Співчуття & 0,98 & 1,6 & 0,92 & 0,76 & 1 & 1,59 & 1 & 2,13 \\
\hline Внутрішнє сприяння & 1,29 & 1,09 & 1,08 & 0,89 & 1,18 & 0,62 & 1,52 & 1,5 \\
\hline Реальне сприяння не на шкоду собі & 4,89 & 1,64 & 4,46 & 2,03 & 4,77 & 1,34 & 5,29 & 1,65 \\
\hline Реальне сприяння на шкоду собі & 2,18 & 1,09 & 2,46 & 1,05 & 2,14 & 1,20 & 2,05 & 1,05 \\
\hline Інтегральна емпатія & 30,2 & 7,87 & 30,3 & 9,78 & 30,3 & 6,67 & 30 & 8,14 \\
\hline
\end{tabular}

Примітка: $M$ - середнє значення, $\sigma$-середнє квадратичне відхилення

Як видно з табл. 2, середні показники інтегральної емпатії як для всієї вибірки, так і для різних за стажем груп відповідають середньому рівню, ближче до межі з високим рівнем, і практично не відрізняються між собою. Найбільшу кількість балів має форма емпатії «реальне сприяння не на шкоду собі» $(\mathrm{M}=4,89, \sigma=1,64)$. Це засвідчує, що, зазвичай, 
психологи під час взаємодії виявляють активне емпатійне ставлення, що пов'язане 3 емоційною i дієвою підтримкою людини, та водночас адекватно оцінюють власні можливості й здатні усвідомлювати міру шкоди для себе.

Меншою мірою презентовано форму емпатії «реальне сприяння на шкоду собі» $(\mathrm{M}=2,18, \sigma=1,09)$ - альтруїстична поведінка, «дієве трансцендентне емпатійне ставлення» (Журавльова, 2011), якщо інтереси, проблеми іншої особи ставляться вище за власні. Наступним за проявом $€$ «внутрішнє сприяння» $(\mathrm{M}=1,29, \sigma=1,09)$ - пасивне емпатійне ставлення до іншого, що пов'язано з його розумінням і моделюванням поведінки.

Найменшою мірою виявляються: «співчуття», як здатність поділяти почуття 3 іншим $(\mathrm{M}=0,98, \sigma=1,60)$; «співпереживання», як реакція на емоційний стан іншого $(\mathrm{M}=0,79, \sigma=1,24)$; «індиферентність», як байдужість до емоцій іншої людини $(\mathrm{M}=0,73$, $\sigma=0,74)$; «антиемпатія», яка характеризується навмисним проявом полярних емоцій до емоційного стану іншого $(\mathrm{M}=0,71, \sigma=0,69)$. Такі показники, в яких спостерігається більший прояв активних форм емпатії, презентують значущість емпатії для професійної діяльності психолога та її сформованість у психологів закладів освіти.

У зіставленні різних форм емпатії психологів виокремлених груп спостерігаються деякі відмінності. Для форм емпатії («реальне сприяння не на шкоду собі», «реальне сприяння на шкоду собі», «внутрішнє сприяння» i «співчуття»), які виявляються найбільшою мірою, зіставлення залишається ідентичним для всіх досліджуваних груп. Однак, зіставивши форми емпатії, які психологи демонструють нечасто, встановлено такі відмінності: «молоді фахівці» частіше демонструють «індиферентність» $(\mathrm{M}=0,85, \sigma=1,33)$, рідше - «співпереживання» $(\mathrm{M}=0,69, \sigma=0,50)$, найрідше - «антиемпатію» $(\mathrm{M}=0,62$, $\sigma=0,82)$; «професіонали» частіше демонструють «співпереживання» $(\mathrm{M}=0,82, \sigma=0,47)$, потім - «індиферентність» $(\mathrm{M}=0,68, \sigma=0,50)$, найрідше - «антиемпатію» $(\mathrm{M}=0,64, \sigma=0,47)$; «майстри» частіше демонструють «антиемпатію $(\mathrm{M}=0,86, \quad \sigma=0,77), \quad$ рідше «співпереживання» $(\mathrm{M}=0,81, \sigma=2,03)$, найрідше - «індиферентність» $(\mathrm{M}=0,71, \sigma=0,50)$.

Зважаючи на одержані результати, можна припустити, що у складних, неприємних ситуаціях взаємодії психологи 3 невеликим стажем виявляють байдужість, відстороненість, психологи зі стажем 4-14 років все ж будуть співпереживати, а психологи 3 великим стажем дозволять собі переживати негативні емоції, ворожість і небажання розуміти й підтримувати іншу людину.

Результати порівняльного аналізу форм емпатії психологів освітніх закладів із різним стажем професійної діяльності подано в табл. 3.

Порівняльний аналіз показників емпатії у групах із різним стажем практичної діяльності за допомогою непараметричного критерію Манна-Уїтні (див. табл. 3) засвідчив, що статистично значущих відмінностей у формах емпатії між виокремленими групами психологів закладів освіти немає. Ці результати не відповідають сталій ідеї про те, що емпатія більш досвідчених практичних психологів виявляється на більш високому рівні, порівняно 3 психологами-«початківцями». Розуміння переживань іншого, прояви співчуття та дії з підтримки іншої людини виявляються майже однаково у психологів із різним стажем роботи за фахом, що узгоджується з результатами інших досліджень (Goussakovski \& Sizikova, 2017). 
Результати порівняльного аналізу форм емпатії психологів освітніх закладів із

Таблиия 3 різним професійним стажем

\begin{tabular}{|c|c|c|c|c|c|}
\hline \multirow[t]{3}{*}{ Форми емпатії } & \multirow{3}{*}{$\begin{array}{c}\text { Групи } \\
\text { психологів } \\
\text { (за стажем) }\end{array}$} & \multicolumn{4}{|c|}{ Групи психологів (за стажем) } \\
\hline & & \multicolumn{2}{|c|}{ 4-14 років } & \multicolumn{2}{|c|}{ 15-26 років } \\
\hline & & $\mathrm{U}$ & $p$ & $\mathrm{U}$ & $p$ \\
\hline \multirow[t]{2}{*}{ Антиемпатія } & 0,5-3 років & 127,5 & 0,6 & 106 & 0,28 \\
\hline & 4-14 років & & & 203,5 & 0,5 \\
\hline \multirow[t]{2}{*}{ Індиферентність } & 0,5-3 років & 140,5 & 0,93 & 131 & 0,85 \\
\hline & 4-14 років & & & 225,5 & 0,89 \\
\hline \multirow[t]{2}{*}{ Співпереживання } & $0,5-3$ років & 118 & 0,39 & 130,5 & 0,83 \\
\hline & 4-14 років & & & 183 & 0,24 \\
\hline \multirow[t]{2}{*}{ Співчуття } & 0,5-3 років & 133 & 0,73 & 117 & 0,49 \\
\hline & 4-14 років & & & 215 & 0,7 \\
\hline \multirow[t]{2}{*}{ Внутрішнє сприяння } & $0,5-3$ років & 130 & 0,66 & 113 & 0,4 \\
\hline & 4-14 років & & & 214,5 & 0,69 \\
\hline \multirow[t]{2}{*}{ Реальне сприяння не на шкоду собі } & 0,5-3 років & 131 & 0,68 & 105 & 0,26 \\
\hline & 4-14 років & & & 188 & 0,3 \\
\hline \multirow[t]{2}{*}{ Реальне сприяння на шкоду собі } & $0,5-3$ років & 122,5 & 0,48 & 109 & 0,33 \\
\hline & 4-14 років & & & 224 & 0,86 \\
\hline \multirow[t]{2}{*}{ Інтегральна емпатія } & 0,5-3 років & 125,5 & 0,55 & 124,5 & 0,67 \\
\hline & 4-14 років & & & 228,5 & 0,95 \\
\hline
\end{tabular}

Примітка: U - значення U-критерію Манна-Уітні, p - рівень статистичної значущзості

Для більш глибокого аналізу динаміки емпатії на різних етапах професіоналізації було розраховано зв'язок показників різних форм емпатії зі стажем і віком досліджуваних за допомогою коефіцієнта рангової кореляції Спірмена (табл. 4).

Таблиия 4

Кореляція показників різних форм емпатії зі стажем і віком психологів освітніх закладів

\begin{tabular}{|l|c|c|c|c|}
\hline \multirow{2}{*}{\multicolumn{2}{|c|}{ Форми емпатії }} & \multicolumn{3}{c|}{ Коефіцієнт кореляції Спірмена } \\
\cline { 2 - 5 } & \multicolumn{2}{|c|}{ зі стажем } & \multicolumn{2}{c|}{ з віком } \\
\cline { 2 - 5 } & Spearman R & $\mathrm{p}$ & Spearman R & $\mathrm{p}$ \\
\hline Антиемпатія & 0,22 & 0,12 & $-0,03$ & 0,82 \\
\hline Індиферентність & 0,06 & 0,64 & $-0,13$ & 0,34 \\
\hline Співпереживання & $-0,02$ & 0,86 & $-0,15$ & 0,29 \\
\hline Співчуття & $-0,16$ & 0,24 & $-0,39$ & 0,003 \\
\hline Внутрішнє сприяння & 0,12 & 0,39 & 0,07 & 0,63 \\
\hline Реальне сприяння не на шкоду собі & 0,08 & 0,57 & 0,18 & 0,2 \\
\hline Реальне сприяння на шкоду собі & $-0,14$ & 0,31 & 0,07 & 0,62 \\
\hline Інтегральна емпатія & $-0,10$ & 0,46 & 0,3 & 0,03 \\
\hline
\end{tabular}

Примітка: Spearman $R$ - значення коефіцієнта рангової кореляції Спірмена, $p$ - рівень статистичної значущості

Аналіз даних кореляції різних форм емпатії зі стажем досліджуваних (для всієї вибірки) засвідчує їх слабкий зв'язок або відсутність зв'язку між ними. Проте, аналіз показників кореляції форм емпатії з віком досліджуваних демонструє помірний обернений 
зв'язок між віком i співчуттям $(\mathrm{p} \leq 0,01)$ i слабкий прямий зв'язок між віком та інтегральною емпатією $(\mathrm{p} \leq 0,05)$. Тобто, чим старший психолог, тим вищий рівень його емпатії, хоча при цьому він менше співчуває іншим, менше виявляє здатність поділяти почуття з іншим, менше переживає з приводу почуттів іншого, менше стає на позицію партнера по спілкуванню в оцінці його почуттів.

Дані кореляції різних форм емпатії зі стажем у групах психологів, відмінних за стажем, демонструють досить цікаві результати (табл. 5). Якщо у групі «професіоналів» $\mathrm{i}$ «майстрів» зв'язок між емпатією і стажем відсутній, то у групі «молодих фахівців» існує тісний обернений $(\mathrm{p} \leq 0,01)$ зв'язок між стажем та інтегральною емпатією i прямий суттєвий $(\mathrm{p} \leq 0,05)$ - між стажем та антиемпатією.

Таблиия 5

Кореляція показників форм емпатії зі стажем досліджуваних (у групах психологів, відмінних за стажем)

\begin{tabular}{|l|c|c|c|c|c|c|}
\hline \multirow{2}{*}{ Форми емпатії } & \multicolumn{6}{|c|}{ Коефіціснт кореляції Спірмена } \\
\cline { 2 - 7 } & \multicolumn{2}{|c|}{$0,5-3$ років } & \multicolumn{2}{c|}{ 4-14 років } & \multicolumn{2}{c|}{$15-26$ років } \\
\cline { 2 - 7 } & $\begin{array}{c}\text { Spearman } \\
\mathrm{R}\end{array}$ & $\mathrm{p}-$ level & $\begin{array}{c}\text { Spearman } \\
\mathrm{R}\end{array}$ & $\mathrm{p}$-level & $\begin{array}{c}\text { Spearman } \\
\mathrm{R}\end{array}$ & $\mathrm{p}$-level \\
\hline Антиемпатія & 0,59 & 0,03 & 0,19 & 0,4 & $-0,0004$ & 0,99 \\
\hline Індиферентність & 0,37 & 0,21 & 0,129 & 0,59 & $-0,04$ & 0,85 \\
\hline Співпереживання & 0,25 & 0,42 & $-0,109$ & 0,65 & 0,05 & 0,83 \\
\hline Співчуття & $-0,32$ & 0,292 & $-0,119$ & 0,62 & $-0,19$ & 0,41 \\
\hline Внутрішнє сприяння & $-0,42$ & 0,152 & 0,22 & 0,33 & 0,03 & 0,89 \\
\hline $\begin{array}{l}\text { Реальне сприяння не } \\
\text { на шкоду собі }\end{array}$ & $-0,32$ & 0,282 & $-0,3$ & 0,17 & $-0,21$ & 0,37 \\
\hline $\begin{array}{l}\text { Реальне сприяння на } \\
\text { шкоду собі }\end{array}$ & $-0,37$ & 0,212 & $-0,21$ & 0,36 & 0,19 & 0,41 \\
\hline Інтегральна емпатія & $-0,79$ & 0,001 & $-0,19$ & 0,39 & 0,14 & 0,54 \\
\hline
\end{tabular}

Примітка: Speаrтап $R$ - значення коефіцієнту рангової корелячії Спірмена, $p$-рівень статистичної значущості

Як видно з табл. 5, у перші три роки професійної діяльності практичного психолога відбуваються досить інтенсивні зміни у розвитку емпатії, а саме - зменшення ії загального прояву, водночас прояви антиемпатії збільшуються. На нашу думку, це можна пояснити тим, що в перші три роки роботи у закладах освіти відбувається адаптація фахівців до специфічних умов діяльності, інтенсивних соціальних контактів, частої взаємодії 3 клієнтами різного віку з різними проблемами, і молоді психологи можуть реагувати на таке «комунікативне» навантаження зростанням неприйняття іншої людини, iі особливостей і проблем заради збереження власного психічного здоров'я. 3 огляду на невеликий професійний досвід, психолог-«початківець» не завжди може вибрати форми взаємодії з клієнтами, адекватні ситуації, в складних ситуаціях може виявляти ворожість.

У групах психологів з більшим стажем («професіоналів» і «майстрів») кореляції емпатії зі стажем не виявлено. Відсутність подібного зв'язку можна пояснити так. Поперше, 1-3 роки практичної діяльності надають змогу психологам зрозуміти наскільки ця сфера діяльності підходить їм і змінити ії у випадку, якщо вона не відповідає їхнім особистісним i професійним можливостям, унаслідок чого фахівці 3 низькою емпатійністю не залишаються у професії. По-друге, в результаті адаптації до професійних 
умов, психологи знаходять баланс між своїми можливостями та необхідністю розуміння й прийняття клієнта. По-третє, досвід роботи дозволяє фахівцю виробити індивідуальний стиль діяльності, враховуючи свої «сильні» якості та уникаючи ситуацій, з якими він не може впоратися. Це узгоджується з висновками інших дослідників про те, що на етапах професіоналізації й майстерності «психологи, що залишаються у професії, набувають навиків інтеграції, здатні до ефективної самовіддачі без переживання втрати власного «Я»» (Немолот \& Зубова, $2013: 41)$.

Проаналізуємо детальніше особливості розвитку емпатійності психологів системи освіти у контексті суб'єктивного переживання професійного становлення, звертаючись до результатів, отриманих за методикою «Професійний шлях». У всіх досліджуваних, які працюють у закладах освіти перший рік, рівень емпатії високий або на межі з високим. Емоційний фон всіх подій, значущих для професійного становлення, позитивний, навіть ейфорійний. Водночас типовими труднощами їхнього професійного становлення частіше виступають: емоційні проблеми, наприклад, тривога, особистісні страхи, а також відсутність досвіду роботи, великий обсяг роботи, нове оточення, бар'єри у спілкуванні. Підсумками значущих професійних подій досліджувані вважають нові знайомства, налагодження стосунків 3 колегами, набуття професійних навичок і знань, новий досвід, професійне зростання, аж до «розуміння власного призначення», «відчуття безмежних ресурсів любові до дітей» тощо.

На другому році роботи характер висловлювань психологів змінюється - вони розповідають про різні події без емоційного піднесення. Результатом цих подій називають підвищення професійного рівня, зокрема, отримання різноманітних сертифікатів, набуття навичок ведення документації, консультації у досвідчених спеціалістів 3 приводу роботи тощо. На третьому році роботи емоційні оцінки професійно значущих подій часто мають амбівалентний характер. Професійні проблеми найчастіше пов'язані з власне виконанням діяльності, наприклад, «спочатку важко було визначити характер проблематики, потім виникли складнощі у налагодженні взаємодії з дитиною, а коли проводились заняття, результату не було». Серед підсумків подій, поряд із професійним зростанням, з'являються сумніви щодо продовження роботи («Я до кінця не знаю, чи хочу працювати за спеціальністю»). Отож, у суб'єктивних переживаннях професійного становлення у перші три роки роботи психологом у системі освіти спостерігається зміна емоцій від піднесених, ейфорійних до амбівалентних, характеру труднощів - від емоційних до виконавчих, суб'єктивних підсумків - від нового досвіду до сумнівів щодо своєї діяльності. Такі переживання призводять до зниження інтегральної емпатії й окремих проявів неприйняття інших людей, їх проблем на тлі власних труднощів.

Результати вивчення суб'єктивного переживання професійного становлення психологами зі стажем 4-14 років свідчать, що вони часто сприймають свій професійний шлях обмежено, розпочинаючи з пошуку роботи, працевлаштування і не згадуючи про вибір професії, навчання у виші. Емоційні оцінки професійно значущих подій часто мають амбівалентний і негативний характер. У формулюванні труднощів і підсумків подій виявляється інтернальний локус контролю, орієнтація на себе, свої особливості, якості, потреби, можливості.

Психологам зі стажем 15-26 років власний професійний шлях уявляється цілісним і включає вибір професії, професійне навчання, початок роботи, іiї зміни, підвищення 
кваліфікації, а також сімейні події. Серед підсумків професійних подій часто зазначалося про досягнення, наприклад, «тренер та спікер на фестивалях арт-терапії», «створення власного продукту - авторських метафоричних карт» та ін.

У групах «професіоналів» і «майстрів» респонденти 3 високим рівнем емпатії відрізняються високою емоційністю та орієнтацією на інших людей. Професійні події у них часто пов'язані з невпевненістю, сумом, іноді страхом. Серед професійних труднощів зазначено: вимоги роботодавців, невеликий досвід, неадекватність керівника, необхідність завоювати авторитет у колег, адміністрації. Результатами подій часто є дії з боку інших, їхнє схвалення, наприклад, «теплі посмішки, інтерес в очах присутніх», «повага колег».

Отже, після періоду професійної адаптації ставлення до власної професії у психологів системи освіти вже має менш емоційний, більш реалістичний та «інструментальний» характер, з подальшою інтеграцією іiі складових і життя загалом. Емпатія досвідчених психологів носить досить сталий характер. Ї̈̈ зависокий рівень, можливо, пов'язаний із екстернальним локусом контролю та високою емоційністю, що є певними факторами ризику для виникнення емоційного вигорання.

\section{Висновки}

Отже, результати проведеного дослідження надали можливість визначити особливості емпатії практичних психологів освітніх закладів на різних етапах їхнього професійного становлення. Найбільш характерним для них $є$ середній і високий рівень емпатійності. Серед форм емпатії домінують активні емпатійні ставлення, пов'язані 3 емоційною і дієвою підтримкою іншої людини. Прояви емпатії певною мірою пов'язані 3 віком: чим старший психолог, тим вища його загальна емпатійність. Між групами психологів з різним стажем практичної діяльності статистично значущих відмінностей у проявах емпатії не було виявлено. Зв’язок емпатії зі стажем виявлено лише в групі «молодих фахівців» - у перші три роки роботи в закладах освіти у психологів емпатійність зменшується і збільшуються прояви антиемпатії. Трансформація емпатії на різних етапах професіогенезу пов'язана зі змінами в емоційних переживаннях професійно значущих подій, оцінках їх наслідків, характері труднощів.

Перспективи подальших досліджень вбачаємо у вивченні зв'язку емпатії психологів з їхнім локусом контролю, а також розробці та апробації програми розвитку оптимальних емпатійних ставлень для попередження емоційного вигорання, збереження психічного здоров'я.

\section{Література}

1. Бодалев, А.А. (1996). Психология общения. Москва : Ин-т практ. психологии.

2. Бойко, В.В. (2004). Энергия эмоциий. Санкт-Петербург : Питер.

3. Бражникова, А.Н. (2012). Эмпатия как нравственное качество будущего профессионала. Психологическая наука и образование, 4.

Режим доступу: http://psyedu.ru/journal/2012/4/3152.phtml

4. Гаврилова, Т.П. (1974). Экспериментальное изучение эмпатии у детей младшего и среднего школьного возраста. Вопросы психологии, 5, 107-114.

5. Гиппенрейтер, Ю.Б., Карягина, Т.Д., \& Козлова, Е.Н. (1993). Феномен конгруэнтной эмпатии. Вопросы психологии, 4, 61-68.

6. Горностай, П.П. (2018). Консультативная психология: Теория и практика проблемного подхода. Киев : Ника-Центр.

7. Дерев'янко, С.П. (2015). Характеристики емпатії студентів-психологів. Вісник Чернігівського національного педагогічного університету. Серія: Психологічні науки, $126,70-74$. 
8. Журавльова, Л.П. (2007). Психологія емпатії. (Монографія). Житомир : ЖДУ ім. I. Франка.

9. Журавльова, Л.П. (2011). Діагностика емпатії особистості зрілого віку. Психологічні перспективи. Спеціальний випуск. Психологічні виміри украӥнського соціокультурного простору, 12-19.

10. Карягина, Т.Д. (2010). Проблема формирования эмпатии. Консультативная психология и психотерапия, 1, 38-54.

11. Мітіна, С.В. (2017). Емпатія як професійно важлива якість медичного фахівця. Науковий вісник Херсонського державного університету, 1(1), 83-88.

12. Немолот, Е.В., \& Зубова, С.И. (2013). Возможности изучения самооценки профессионально важных качеств педагогов-психологов. Вестник ТГПУ, 9(137), 37-43.

13. Пирог, Г.В. (2020). Психологічні особливості та проблеми професійного становлення студентів-психологів. Особистісне зростання в умовах трансформацї сучасного суспільства. (Монографія). Житомир : Вид. О.О. Свенок.

14. Чаплак, Я.В. (2018). Проблема емпатії в психології та ії важливість у професійному $\begin{array}{llll}\text { становленні психолога. Psychological Journal, } & \text { 5(15), }\end{array}$ https://doi.org/10.31108/1.2018.5.15

15. Штих, I.I. (2015). Здатність до емпатії як компонент професійних здібностей психолога. Науковий вісник Мукачівського державного університету. Серія «Педагогіка та психологія», 2(2), 177-180.

16. Barrett-Lennard, G.T. (1981). The empathy cycle: Refinement of a nuclear concept. Journal of Counseling Psychology, 28(2), 91-100. https://doi.org/10.1037/0022-0167.28.2.91

17. Craig, C.D., \& Sprang, G. (2009). Compassion satisfaction, compassion fatigue, and burnout in a national sample of trauma treatment therapists. Anxiety, Stress \& Coping. An International Journal, 319-339.

18. Derksen, F., Bensing, J., \& Lagro-Janssen, A. (2013). Effectiveness of empathy in general practice: a systematic review. British Journal of General Practice, 63(606): 76-84. https://bjgp.org/content/63/606/e 76

19. Elliott, R., Bohart, A.C., Watson, J.C., \& Greenberg, L.S. (2011). Empathy. Psychotherapy, 48(1), 43-49. https://doi.org/10.1037/a0022187

20. Goldstein, A.P., Michaels, G.Y. (1985). Empathy development training, consequences. New Jersy, London.

21. Goussakovski, V., \& Sizikova, M. (2017). Paradoxical Findings Regarding Therapist Empathy Based on Length of Professional Experience. Transactional Analysis Journal, 47(2), 112-125. https://doi.org/10.1177/0362153717691976

22. Hakansson, J. (2003). Exploring the phenomenon of empathy. Doctoral Dissertation, Stockholm University.

Retrieved from http://www.emotionalcompetency.com/papers/empathydissertation.pdf

23. Hong, H., \& Han, A. (2020). A systematic Review on Empathy Measurement Tools for Care Professionals. Educational Gerontology, 46(2), 72-83.

https://doi.org/10.1080/03601277.2020.1712058

24. Lu, Y., Hill, C.E., Hancock, G.R., \& Keum, B.T. (2020). The effectiveness of helping skills training for undergraduate students: Changes in ethnocultural empathy. Journal of Counseling Psychology, 67(1), 14-24. https://doi.org/10.1037/cou0000404

25. Neumann, M., Bensing, J., Mercer, S., Ernstmann, N., Ommen, O., \& Pfaff, H. (2009). Analyzing the «Nature» and «Specific Effectiveness» of Clinical Empathy: A Theoretical Overview and Contribution Towards a Theory-based Research Agenda. Patient Education and Counseling, 74(3), 339-346.

26. Rogers, C. (1995). Empatic: an unappreciated way of being. Houghton Mifflin Harcourt.

\section{References}

1. Bodalev, A.A. (1996). Psihologiya obscheniya [Psychology of communication]. Moskva : In-t prakt. psikhologii [in Russian].

2. Boyko, V.V. (2004). Energiya emotsiy [Energy of emotions]. Sankt-Peterburg : Piter [in Russian].

3. Brazhnikova, A.N. (2012). Empatiya kak nravstvennoe kachestvo buduschego professionala [Empathy as the moral quality of a future professional]. Psihologicheskaya nauka $i$ obrazovanie - Psychological Science and Education, 4.

Retrieved from http://psyedu.ru/journal/2012/4/3152.phtml [in Russian]. 
4. Gavrilova, T.P. (1974). Eksperimental'noye izucheniye empatii u detey mladshego i srednego shkol'nogo vozrasta [An experimental study of empathy in children of primary and secondary school age]. Voprosyi psihologii-Psychology Issues, 5, 107-114 [in Russian].

5. Gippenreyter, Yu.B., Karyagina, T.D., \& Kozlova, E.N. (1993). Fenomen kongruentnoy empatii [The phenomenon of congruent empathy]. Voprosyi psihologii - Psychology Issues, 4, 61-68 [in Russian].

6. Gornostay, P.P. (2018). Konsultativnaya psihologiya: Teoriya i praktika problemnogo podhoda [Consultatory Psychology: Theory and Practice of the Problematic Approach]. Kiev [in Ukrainian].

7. Derev'yanko, S.P. (2015). Xaraktery`sty`ky` empatiyi studentiv-psy`xologiv [Characteristics of empathy of students-psychologists]. Visny $k$ Chernigivs kogo nacional nogo pedagogichnogo universy tetu. Seriya: Psyxologichni nauky' - Bulletin of Chernihiv National Pedagogical University. Series: Psychological Sciences, 126, 70-74 [in Ukrainian].

8. Zhuravlova, L.P. (2007). Psykholohiia empatii [Psychology of empathy]. Zhytomyr : ZHDU im. I. Franka [in Ukrainian].

9. Zhuravlova, L.P. (2011). Diahnostyka empatii osobystosti zriloho viku [Diagnosis of mature personality empathy]. Psykholohichni perspektyvy. Spetsialnyi vypusk. Psykholohichni vymiry ukrainskoho sotsiokulturnoho prostoru - Psychological Perspectives. Special Issue. Psychological Dimensions of the Ukrainian Socio-cultural Space, 12-19 [in Ukrainian].

10. Karyagina, T.D. (2010). Problema formirovaniya empatii [The problem of empathy development]. Konsultativnaya psihologiya $i$ psihoterapiya - Counseling Psychology and Psychotherapy, 1, 38-54 [in Russian].

11. Mitina, S.V. (2017). Empatiya yak profesijno vazhly`va yakist` medy`chnogo faxivcya [Empathy as a professionally important quality of a medical professional]. Naukovy $j$ visny $k$ Xersons 'kogo derzhavnogo universy`tetu - Scientific Bulletin of Kherson State University, $1(1), 83-88$ [in Ukrainian].

12. Nemolot, E.V., \& Zubova, S.I. (2013). Vozmozhnosti izuchenija samoocenki professional'no vazhnyh kachestv pedagogov-psihologov [Opportunities for studying selfesteem of professionally important qualities of educational psychologists]. Vestnik TGPU TSPU Bulletin, 9(137), 37-43 [in Russian].

13. Pyroh, H.V. (2020). Psykholohichni osoblyvosti ta problemy profesiinoho stanovlennia studentiv-psykholohiv [Psychological features and problems of professional formation of psychology students]. Osobystisne zrostannia $v$ umovakh transformatsii suchasnoho suspilstva - Personal growth in the conditions of transformation of modern society. Zhytomyr : Vyd. O.O. Yevenok [in Ukrainian].

14. Chaplak, Y. (2018). Problema empatiyi v psy’xologiyi ta yiyi vazhly`vist' u profesijnomu stanovlenni psy xologa [The problem of empathy in psychology and its importance in the professional development of a psychologist]. Psychological Journal, 5(15), 24-39. https://doi.org/10.31108/1.2018.5.15 [in Ukrainian].

15. Shty`x, I.I. (2015). Zdatnist` do empatiyi yak komponent profesijny`x zdibnostej psy`xologa [The ability to empathize as a component of the professional abilities of a psychologist]. Naukovy j visny`k Mukachivs kogo derzhavnogo universy`tetu. Seriya "Pedagogika ta psy xologiya» - Scientific Bulletin of Mukachev State University. Series "Pedagogy and Psychology», 2(2), 177-180 [in Ukrainian].

16. Barrett-Lennard, G.T. (1981). The empathy cycle: Refinement of a nuclear concept. Journal of Counseling Psychology, 28(2), 91-100. https://doi.org/10.1037/0022-0167.28.2.91

17. Craig, C.D., \& Sprang, G. (2009). Compassion satisfaction, compassion fatigue, and burnout in a national sample of trauma treatment therapists. Anxiety, Stress \& Coping. An International Journal, 23(3), 319-339.

18. Derksen, F., Bensing, J., \& Lagro-Janssen, A. (2013). Effectiveness of empathy in general practice: a systematic review. British Journal of General Practice, 63(606): 76-84. https://bjgp.org/content/63/606/e 76

19. Elliott, R., Bohart, A.C., Watson, J.C., \& Greenberg, L.S. (2011). Empathy. Psychotherapy, 48(1), 43-49. https://doi.org/10.1037/a0022187

20. Goldstein, A.P., \& Michaels, G.Y. (1985). Empathy development training, consequences. New Jersy, London.

21. Goussakovski, V., \& Sizikova, M. (2017). Paradoxical Findings Regarding Therapist Empathy Based on Length of Professional Experience. Transactional Analysis Journal, 47(2), 112-125. https://doi.org/10.1177/0362153717691976

22. Hakansson, J. Exploring the phenomenon of empathy. Doctoral Dissertation, Stockholm University, 2003.

Retrieved from http://www.emotionalcompetency.com/papers/empathydissertation.pdf 
23. Hong, H., \& Han, A. (2020). A systematic Review on Empathy Measurement Tools for Care Professionals. Educational Gerontology, 46(2), 72-83.

https://doi.org/10.1080/03601277.2020.1712058

24. Lu, Y., Hill, C.E., Hancock, G.R., \& Keum, B.T. (2020). The effectiveness of helping skills training for undergraduate students: Changes in ethnocultural empathy. Journal of Counseling Psychology, 67(1), 14-24. https://doi.org/10.1037/cou0000404

25. Neumann, M., Bensing, J., Mercer, S., Ernstmann, N., Ommen, O., \& Pfaff, H. (2009). Analyzing the «Nature» and «Specific Effectiveness» of Clinical Empathy: A Theoretical Overview and Contribution Towards a Theory-based Research Agenda. Patient Education and Counseling, 74(3), 339-346.

26. Rogers, C. (1995). Empatic: an unappreciated way of being. Houghton Mifflin Harcourt.

\title{
PECULIARITIES OF EMPATHY AT DIFFERENT STAGES OF PROFESSIONAL FORMATION OF PRACTICAL PSYCHOLOGISTS OF THE EDUCATION SYSTEM Hanna Pyroh
}

PhD in Philosophy, Associate Professor, Associate Professor of the Department of Developmental Psychology and Counseling Zhytomyr Ivan Franko State University,

40, Velyka Berdychivska Str., Zhytomyr, Ukraine, 10008 sevtur73@gmail.com, https://orcid.org/0000-0002-5139-0286

\author{
Nataliia Shykyrava \\ Methodologist of the Psychological Service of the Scientific and Methodological Center \\ Department of Education of Zhytomyr City Council \\ 7, Berdychivska Str., Zhytomyr, Ukraine, 10014 \\ shukurava1976@ukr.net, https://orcid.org/0000-0002-8903-1027
}

\begin{abstract}
Research on empathy and its changes at different stages of professional development is important for preventing the emotional burnout of specialists, preserving their psychological health. The purpose of our research was to study the features of empathy in practical psychologists of the education system at different their professional formation stages. "Test on empathy determination" by L. Zhuravliova was used to study indicators of empathy empirically. Technique "Professional pathway" by $\mathrm{H}$. Pyroh was applied to find out the peculiarities of the subjective experience of the different professional development stages.

The results of the study showed that the most typical empathy level for the education system psychologists is the medium and high levels. Active empathic attitudes related to emotional and effective support dominate among other forms of empathy. Empathy is connected with age older psychologists have higher overall empathy, however, they are less concerned about the feelings of others. The connection between empathy and work experience is displayed only in the group of "young professionals". At the beginning of the psychologist's practical professional activity there is a quite intense transformation in the manifestation of empathy towards diminishing its overall expression and increasing of antiempathy. This is explained by changes in the emotional evaluations of professionally significant events, their outcomes, the nature of the difficulties, leading to awareness of one's own problems, and a decrease in empathy. An attitude of psychologists to their profession after a professional adaptation begins to have a less emotional and more "instrumental" character. A high level of empathy is manifested among experienced psychologists who are professionally oriented to other people and have high emotionality. Further research is planned to investigate the connection of the practical psychologists' empathy with the locus of control and to create a program for developing optimal empathy attitudes to prevent emotional burnout.
\end{abstract}

Keywords: empathy, empathic attitude, professional formation, practical psychologists, education system, professional pathway.

Подано 25.04.2020

Рекомендовано до друку 10.06.2020 